\title{
Total Quality Management in Higher Education
}

\author{
DR.Majd Mohammad al-omoush ${ }^{1}$, DR.Arwa hisham alrahahleh ${ }^{2}$, DR.Zaid ahmad Alabaddi ${ }^{3}$ \\ 1. ministry of education ,Jordan
}

2. the College of Business Administration and Economics,Al-Hussein Bin Talal University, P.O. Box 20 Ma'an, Jordan

3. the College of Business Administration and Economics,Al-Hussein Bin Talal University, P.O. Box 20 Ma'an, Jordan

\begin{abstract}
This research paper aims at highlighting the Total Quality Management (TQM) elements at university, through environmental scanning the researcher found many important factors in University, where quality of education Is the main purpose of a university education when providing service for students. A lot of researcher have been studied (TQM) around the world by educational institution, that's indicators how is very important quality assurance in education sector based on revolution and hyper competition between institution specially university. accordingly this paper focus on TQM as a approach used in organization to enhance managerial method pulse increase the performance at university output. so the main objectives in this paper to concentration on principle of TQM. Also, it studies the core concept of principle and highlight on important part that enhances the quality in university plus that what the distinguish from others papersto achieve academic excellence.
\end{abstract}

Key words: Higher education, quality, Total Quality Management, academic excellence, Jordan.

\subsection{Introduction}

Globalization and competition motivated higher education institution to change processes to engage with external forces and a new technology based on supply and demand (Temple, 2005; Mehralizadeh, 2005; Srikanthan, 2003).at all kind of institution work in a university, a bank, a hospital , an airline , a privet company, and government organization all these institution competition for client, for student, for customers for wealth, For money to get high reputation in quality service like price , reliability ,durability but the quality is the most important in competition at the current situation (okaland, 2002). Higher Education is one of the important service sectors in modern business so all the time, any sector is always in a condition of new change and is being motivated by the public ,government and economic necessary (Tahar, 2008). The benefit of the development for excellence education, capability and Evolution of knowledge force growth and enlargement in economy and unstable so, most institution in higher education around world should establish strategy for development in education. TQM is the most important factor that shape the strategies of higher education institution in their attempt to variety stockholders as well as parents, student and society as a whole Ali et al., (2009).

All researchers such as Sirvanci, (2004), Guzman et al., (2004), And Najafabadi et al., (2008) Adopted that TQ Institution applied TQM had been successfully and enhance

the difficulty and challenges for the educational center piece that operates in an environment of quality.while their research in higher education focus to $r$ sharing learning and knowledge through department and function , it was ironic that they have been lagging behind other organizations in approval and implementing TQM as shown by Sirvanci, (2004).

Where this inactivity in the adoption of TQM shows usual characteristics and traditional structure of higher education academy still through challenges are not encountered in other institutions services. Finally, Quality education is aimed by quality-motivated activity efforts and practices. Philosophy of TQM the most important subject in educational management on the way to identify how 14 institutional preparation and planning is work plus how benchmarking is practiced and adapted, taking into account the university's levels and rank of capability and cope-facility (Guzman et al., (2004).

\subsection{Research aim and Objectives}

The academic institutions are facing enormous challenges in the twenty-first century as a result of globalization and the communications revolution and Internet with cultural challenges and technology diverse as the challenges imposed on the universities of interest to developing quality educational services and to continuous improvement Temponi, (2005) and rapid development. Traditional administration is unable to face challenges so it must be orientation to use the modern management concepts such as total quality management the objectives of this research are:

a) To clarify the core concept of the principles of TQM and to achieve academic excellence.

b) To determine the extent of senior management commitment to the application of TQM.

c) To identify if the university present necessary services to students, employees and teachers and To 
show possible mistakes expected in TQM applying in education.

d) To determine TQM requirements for the learning process to access academic excellence.

\section{Literature Review}

Literature Review the part gives the person who reads an overview of variety contribution in literature related with the TQM in higher education which includes the concept of quality, TQM in higher education, customer in higher education and principle to applying TQM in university, function of higher education also Identify the principles for TQM and the core concept for this principles that will be used in this research through Taxonomy in Table (1) and Table (2) that have been extracted from previous studies.

\subsection{Concept of Quality.}

Quality word which means what kind of, is original from Latin word quails, it means a variety of meanings and implies lots of things to different people Ali et al., (2010). Quality then is simply meeting the customer requirements, and this has been expressed in many Ways by other authors by Oakland, (2002):

Fitness for purpose or use. Juran, an early doyen of quality management. The output of service and product characteristic of engineering producer, marketing and maintenance in uses must be convene the needs and expectation by client and customer. The researcher who is the first person write a book with total quality in the subject of conformance to requirements. And the important subject in quality the Degree to which a set of inherent characteristics fulfils requirements ISO (EN) 9000:2000 Quality Management Systems essentials and expressions indicators by Crosby in the 1980 an the famous consultant in America. In common benefit of quality management to satisfies and meet customers' desires pulse incessantly save on performing with standards that customers needs by Ali et al,(2009). Other wise Oakland said in his book the Quality is often used to explain excellence of a product or service.

\subsubsection{Quality in Higher Education.}

Similar to any other businesses, higher education requirements quality (Samuel, et al., 1995). Sahney et al. (2004). defined the quality of education as processes in the form of the learning and teaching knowledge activity; where quality of outputs is in the form of the enlightened students that shifts out of the organization. Furthermore Ali et al., (2010) Declared that the Quality of education takes into account external environment where institutions work. Also internal environment where education and learning get situate and home environment of learners. The quality of education opportunities would depend on the accomplishment of programmer objectives based on aspects of teaching and learning, student support and direction, learning and resources, and quality management and enrichment (kanji et al.,1999).

\subsubsection{Quality Dimension}

It is importance here to explain the dimensions of the quality, briefly, and to some extent to distinguish the quality dimension in higher education by Owlia et al., (1996). Reliability: the degree to which education is acceptable, accurate and up to date. 2. Responsiveness and customers : its mean of academic lecturer and stuff give the student all what they need to understanding and advice in educational methods. Competence is a capacity in addition capability of knowledge and presentation skills that should have in academic staff. Courtesy teacher touching feeling with students. Communication : make sharing knowledge with student in the class. Credibility how much is consistency. Privacy is related with secure information. Tangible facilities and equipment available in service. completeness it's about skills. flexibility : the level to which knowledge learn Are appropriate toward other fields. Redress how to responsive to the client need and restore the problem if their haven't satisfaction.

\subsection{TQM in Higher Education}

TQM is an approach of management to get better effectiveness, efficiency, cohesiveness, flexibility, and competitiveness of a business as a whole (Samuel, et al., 1996) Consistent with Ali, et al., (2009) The TQM commonly may be able to defined as making right things for the initial time, determined for continuous development, satisfying customers, requirement, making quality of the responsibility of each member of staff.

Sahney et al.,(2002) appointed to TQM in education as complicated, It contains within its domain the quality of inputs in the form of learners, support employees and connections of the processes quality in the form of the education and teaching activity and the quality of outputs in the form of the enlightened students that go out of the system. Moreover Sangeeta et al.,(2004) considered learning system as an alteration process comprising of inputs of students, educators, administrative staff, physical facilities and process.

\subsubsection{TQM principle}

Redmond, et al.,(2008) and (Najafabadi et al.,2008) clarified Edward Deming's contribution to organizational management In addition, more specifically to quality is enormous and is significantly further than the principles. 
six principles concentrated on significant The leadership is very important factor affect on quality of educational institution plus its support the teamwork in the place of work that's decrease the delay and weakness during doing any job .

There are many models, based on the knowledge of quality leaders in general that there are many principles in TQM help educational institution successfully applying like top management, employee participation , training , customer focus, training, continuous improvement. in actual quality wards like Malcolm baldrige in the European and American accepted the most important factors of TQM as their award criteria (sirvanci, 2004).

\subsection{Customers of Higher Education}

Some of agreement indicator the student in higher education is customers to attractive the commercial business as, in an effort to identify their customers, the quality council of a university generated a long list including parents, alumni, employers, society, faculty, local community, academic disciplines, and staff. Without a well defined customer and a customer focus, quality efforts may simply be diffused ( sirvanci, 2004) .

According to Sahney et al., (2002) the students are considered as end customers. Harvard University defines its customer as one to whom we provide information or service. Students who use the institute's service and employers who are consumers of students are regarded as customers. For that reason the customers are students, employers or both. Referring to Span Bauer there are two types of customer: external (students, employers, taxpayers and community at large, other educators from different institutions) and internal (other instructors, service department staff). Moreover to Srivanci, students as customers take four roles: the product in process the internal customers for many campus facilities the employees of awareness process and the internal customers for delivery of course material need are determined by education mix. Via teaching, research and extension activities, defined by (Ali, et al., 2009). Sahney et al. (2004) Said that the higher education has a number of complementary and contradictory customers.

\subsection{University and Function of higher education}

In addition, the university is a place where highly quality training is provided, teaching, learning and extension also a place in which entry depends only on the intellectual merit of the individual and capability to contribute actively in curricular programs and activities which encourage social equity, where updating and continuous improvement of knowledge is fostered which pointed up by Guzman et al., (2004). education system as a transformation process including inputs of students, teachers, administrative staff, physical facilities and process. The processes consist of learning, teaching, and administration. Outputs contain examination results, service, earnings and agreement Sahney et al. (2004).

Consequently the benefits of TQM include heightened employee confidence, enhanced teamwork among departments, bridging faculty-staff jobs, increased quality from customer point of view and permanent development of everyone who is part of higher education institution to achievement the functions of higher education Ail et al., (2010).

\subsection{TQM in Higher Educational Institutions}

TQM is a general management philosophy and a set of tools which allow an institution to follow a definition of quality and a means of attaining quality, with quality being a continuous improvement ascertained by customer's satisfaction with the services they receive. TQM can be applied to higher education, but it must be modified to fully recognize some unique aspects of education via education is a service industry with no visible, tangible produce (Ali, et al., 2009).

As demonstrated in Table 1, the factors (principles) show different previous research studies that will explain in other part of this research paper to applying TQM and meaning for these factors as said by Ali, et al, (2009). Indicated top management organization commitment \& quality council \& Support development activities, Sahney et al.,(2004) defined involvement of all employee skills for administrative staff for development and up gradation of human, technical and theoretical skills and abilities should be concentrated upon by all educational organizations, also defined continuous development tools and skills and practicing these newly developed skills on small achievable tasks and projects. Guzman et al.,(2004) showed to customer focus students as customers of the University and provide comfort to them.

TQM has many faces in higher educational as a result, Srivanci (2004) Who classified critical issues in TQM in higher education contains customer, leadership, identification, educational and organizational transformation. Different business organizations, chancellors and heads of higher educational institution do not enjoy ultimate authority in hiring and firing of personnel and allocating resources. Lack of necessary authority creates it difficult to deploy their values and goals through layers of higher education institutions. deep rooted traditions 
dating back to centuries, a rigid departmental model, inter departmental competition for resources, need of market focus are the organizational and cultural reasons that build it hard to tune in with TQM transformation. uncertainty in customer identification also creates hurdles in TQM achievement.

Table 1: Taxonomy of principles for TQM

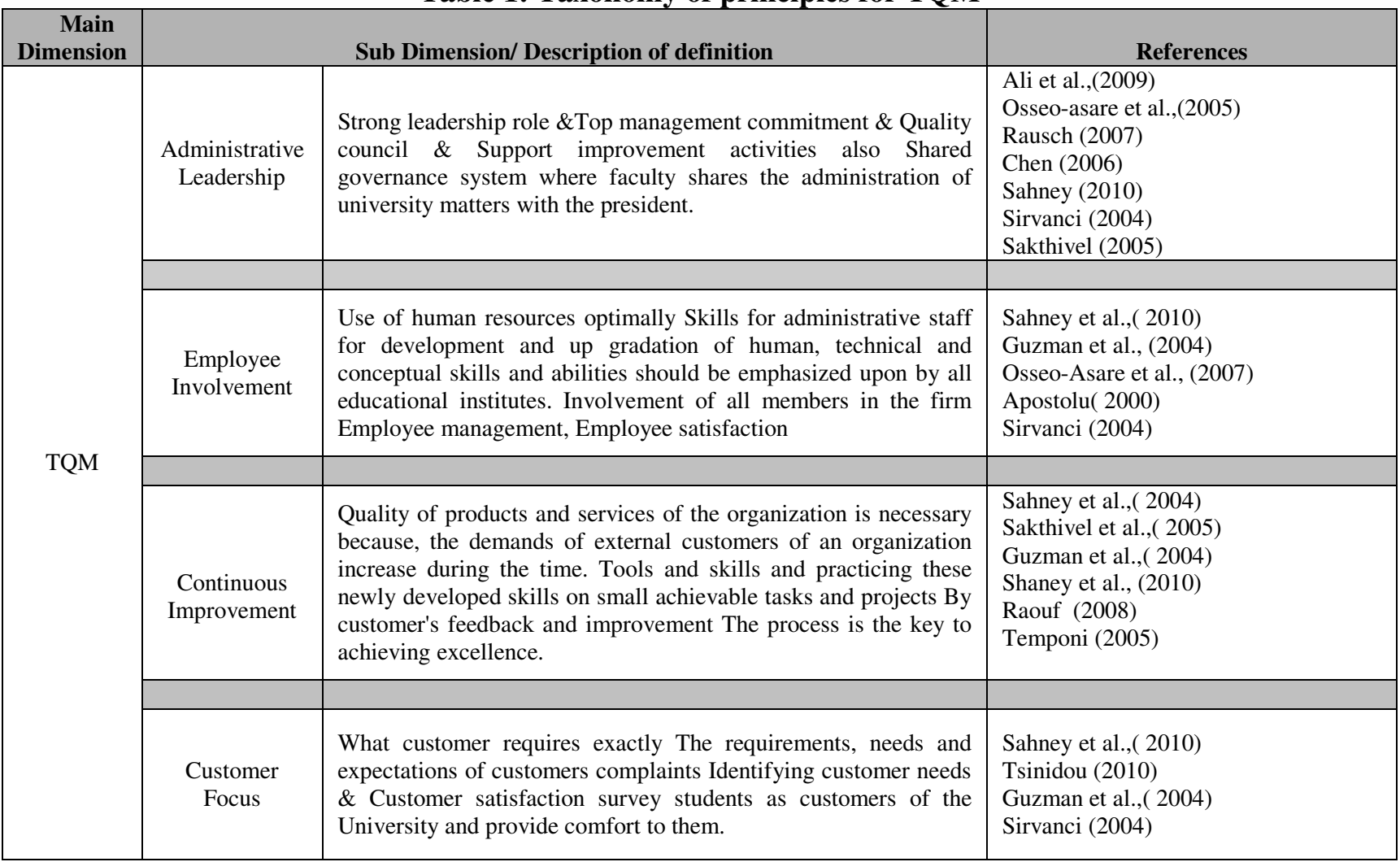

\section{Conceptual Model}

The researcher has suggested that the conceptual model of TQM is based on during investigation of different model presented TQM literature review it's also give feature about the key process based on literature review. Also the model explains the principle of successful applying TQM to higher education through the key of core concepts related with TQM and its impact on achieving academic excellence. as well conceptual of each principle and sub factor in model and clarifies the classification all of sub-factor as shown in figure (1). 


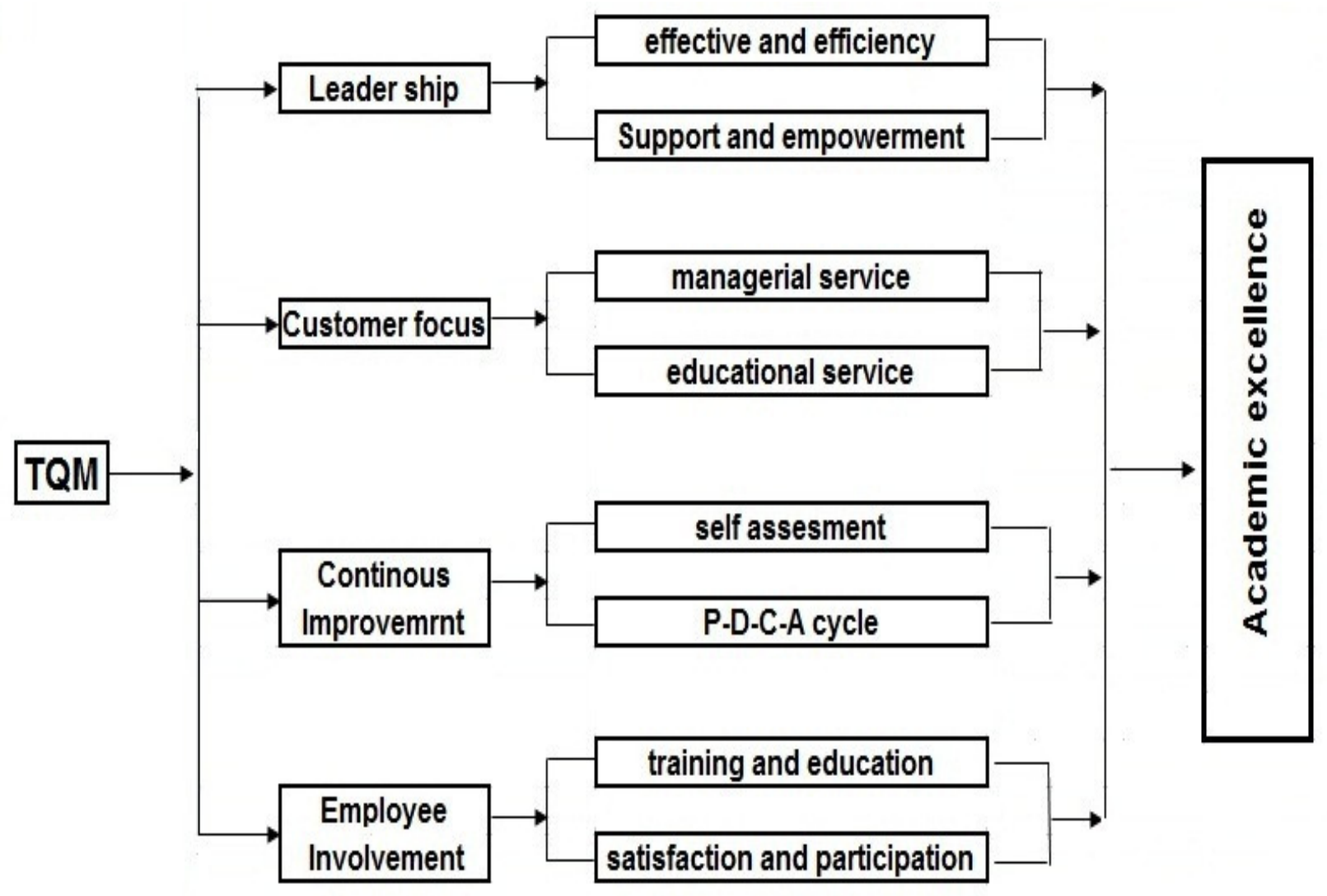

Figure 1. Model of TQM for academic excellence

\subsection{Administrative Leadership with TQM}

Top management's leadership is one of the essential elements of TQM in every country where TQM has been implemented, which explained by Sirvanci,(2004). Strong leadership is needed, transformational management does not direct the faculty and staff as to what to do, but provides opportunities for leadership in performing instructional and organizational tasks as well as assuming responsibility and accountability for consequences and outcomes Supposed by Guzman et al.,(2004). Practice suitable participation in making decision and planning, with consideration or else who should participate, when and how is that as said by (Rausch, 2007).

A satisfied internal customer would act as an efficient service contributor. With the assumption that the agreement of the external customer would have to be preceded by the satisfaction of the internal customer, as related to Sahney, (2010) and Osseo-asare, et al.,(2005) summarized that the leadership practices staff empowerment and support in a holistic way the dynamic form of leadership behavior is possible and feasible in higher education institutions if it embodies the following job qualifications of the person performing the leadership role the job specification of the staff responsible for education and research quality the structure, policy and strategy systems and processes in the place that quality empowerment activities is to be performed and the information, data, intelligence and knowledge derived from the institutions micro, macro and internal environment where table. 2 explains classification for core concept of principles for TQM related to it in previous researches. 
Table 2: Taxonomy of core concepts of principles TQM

\begin{tabular}{|c|c|c|}
\hline Principles & Core concept & Reference \\
\hline Administrative leadership & $\begin{array}{ll}\text { - } & \text { Effectiveness and efficiency } \\
\text { - } & \text { Support and empowerment }\end{array}$ & $\begin{array}{l}\text { Sahney et al.,( 2010) } \\
\text { Guzman et al.,( 2004) } \\
\text { Osseo-Asare et al.,( 2007) }\end{array}$ \\
\hline Employee involvement & $\begin{array}{ll}- & \text { Training and education } \\
\text { - } & \text { Satisfaction and participation }\end{array}$ & $\begin{array}{l}\text { Sahney et al.,( 2010) } \\
\text { Guzman et al.,( 2004) } \\
\text { Chen (2006) } \\
\text { Yang (2006) }\end{array}$ \\
\hline Customer focus & $\begin{array}{ll}\text { - } & \text { Managerial service } \\
\text { - } & \text { Educational service }\end{array}$ & $\begin{array}{l}\text { Sahney et al.,( 2010) } \\
\text { Guzman et al.,( 2004) } \\
\text { Redmond (2008) } \\
\text { Wiklud (2003) }\end{array}$ \\
\hline Continuous improvement & $\begin{array}{l}\text { - Deming Cycle } \\
\text { Self Assessment }\end{array}$ & $\begin{array}{l}\text { Sahney et al.,( 2010) } \\
\text { Guzman et al.,( 2004) } \\
\text { Tsinidous (2010) } \\
\text { Sakthinal (2005) } \\
\text { Petruzzellis (2006) } \\
\text { Sirvanci (2004) } \\
\end{array}$ \\
\hline
\end{tabular}

\subsubsection{Effectiveness and Efficiency}

Sahney., (2010) pointed out that the efficient leadership is to a precondition for the successful functioning of any instructional organization and educational leadership is all pervasive and implies: Keeping a balance among a strong leadership role and maximum self-rule for teachers. Providing a structural institutional model in which teachers can carry out effectively. Being a firm disciplinarian and providing a role-model for teachers and students the same. Performing all managerial functions, from planning to control, setting a strong administrative set up; providing resources and facilities as said by Oakland, (2003).

Effective leadership and total quality management together construct result in the company or organization doing the right things, right first time. Furthermore, clarifying the effective leadership begins with the chief executive's and his top team's vision, capitalizing on market or service opportunities, continues through a strategy that will give the organization competitive or other benefit, and leads to business or service success. It goes on to hold all the beliefs and values held, the results taken and the plans made by anyone or anywhere in the organization, and focusing of them into effective, value-adding action, together, effective leadership and total quality management result in the company or organization doing the right things.

Osseo-Asare et al.,(2007) suggested three things about managerial leadership, Firstly, one that even though there are many alternative bases for exercising leadership, deliberate people-oriented management and leadership behaviors are more likely to lead to major improvement in degree of efficiency and degree of effectiveness of quality management practices in higher education. Secondly, there is a perception gap being between leadership effectiveness in deciding the correct academic quality improvement objectives and management efficiency in the way resources are used to achieve predetermined quality improvement objectives. Finally, additional research is needed to provide in strength explanation of the strategic role of managerial leadership in the successful implementation of TQM in higher education.

\subsubsection{Support and Empowerment}

Empowerment Staff and support most are the respondents and interviewees knowledge that staff empowerment is very significant, but observed that, in an environment where most academics resent formal hierarchical structures leadership practices meant to empower staff as shown by Sahney et al.,(2004), and Okland,(2003).

Beside that, they are simply not effective This is according to some participants, accounts for the high levels of staff dissatisfaction and staff turnover, and low morale, which empowers and supports staff in their effort to improve teaching and research quality, declared by (Osseo-Asare et al., 2007).

\subsection{Employee Involvement with TQM.}

Employee involvement with TQM is a process for empowering employees to participate in managerial decisionmaking and improvement activities appropriate to their levels in the organization. Since McGregor's Theory Y first brought to managers the idea of a participative management style, employee involvement has taken many forms, including the job design approaches and special activities such as quality of work life (QWL) programs (Apostolu, 2000). 
In addition, some employees may acknowledge TQM philosophy but fail to contribute individually because they do not know what is required or are not motivated to participate. Unfortunately, this is particularly acute in higher education where academic staffs are expected to analysis, challenge, and substantiate evidence. Thus, in order to implement TQM effectively, it is important to ensure that everyone is fully involved in and committed to the process Samuel et al ., (1995).

quality improvement starts with the individual faculty member, most instinctively reflect on their teaching processes and the effectiveness of their classes. However, it is important to ensure that faculty do receive useful feedback on their teaching and general performance and are given the opportunity to set goals for the future. Archbold et., al ( 2005).

Apostolu,(2000) clarified that Employee involvement means that every employee is regarded as a unique human being, not just a machine, and each employee is involved in helping the organization meet its goals. Employees and management recognize that each employee is involved in running the business. The goal is to determine the most effective employee involvement options that will be linked to specific organizational goals. In order to implement employee involvement and empowerment to an enterprise, the following key actions need to take place by giving the employee the responsibility, Training employee, Communicating and giving feedback, motivation by rewards.

There is an overpowering amount of confirmation that successful organizations pay much more than lip service to the maintain that people are the most main resource in general, successful level organizations share a basic philosophy to worth and invest in their employees. More specifically, world class organizations value and invest in their people strategic situation of human resource management (HRM) policies. Effective communication training, development teams in addition to teamwork review and continuous improvement according to Oakland, (2003), and (Guzman et al., 2004).

\subsubsection{Training and Education.}

Education and training for quality should have, as its first objective, an appreciation of the personal responsibility for meeting the 'customer' requirements by everyone from the most senior executive to the newest and most junior employee from the viewpoint of Oakland, 2002).

Sahney,(2010) focus on training and development in-service and an on-going procedure for the gaining of knowledge and skills for administrative staff for development and up gradation of human, technical and theoretical skills and abilities should be emphasized upon by all educational associations. Institute Training Establish a mechanism of continuous training on the work for members of the faculty, allied staff and administration of educational institutions. Each of them should go after the vision and mission of the organization through their commitment and improvements in the institution as s shown by Farooq,(2007).

The training and development of people at work has increasingly approach to be recognized as a significant part of human resource management. during the 1980s, most important changes in many organizations resulted in increasing workloads, the introduction of new technology and wider ranges of tasks, all of which required training provision. During the 1990s, initiatives such as ISO 9000, TQM, Investors in People .benchmarking and self assessment next to frameworks such as the EFQM Excellence Model have further highlighted the requirement for properly trained employees, referenced by (Oakland, 2003).

\subsubsection{Satisfaction and Participation}

worker satisfaction is a main driver towards the adoption of a customer orientation by any organization and the educational system is no exception Sahany et al., (2009). According to Sahney, (2010) indicator Reward policy incentives, it is individual based or group based, leading to inspiration and enthusiasm at work. An educational organization must have a fair and transparent reward policy, based on distributive and procedural justice. And Employee approval is a major driver towards adoption of a customer orientation by any organization and the educational system is no exception. Furthermore Yang,(2006), and Chen et al.,(2006) clarified in that model about (teacher satisfaction) similar to work environment, pay and respect, benefit, management system. Organization vision, result feedback and motivation and employee satisfaction like job satisfaction, employee moral, colleagues moral, communication-training-resource-career development ,perceived service quality..

So advantages and rewards are based on appropriate, quality-based performance, awards are given to employees nevertheless also to customers, universities, suppliers, students, colleges, etc. Financial incentives are offered for company-wide propositions and new thought schemes. Commendations contain ad hoc recognition for length of 
service, outstanding contributions, etc. Recognition is given through presentation feedback mechanisms, growth opportunities, pay progressions and bonuses. Recognition systems operate at all levels of the organization but with particular emphasis informal recognition ranging from a personal 'thank you' to recognition at team meetings and events as shown by Oakland (2003).

Participation means that all employees sense that they have the responsibility and authority to participate in decision making and problem solving in their appropriate operating levels. It's obvious that a whole company of skilled and capable problem solvers will have a distinct competitive advantage over an organization with only a few keys contributors Sahney,(2010) focused about sharing and involvement. An institution must adopt and implement a democratic and participative environment where the employees sense free to offer ideas and suggestions.

\subsection{Customer Focus with TQM}

Customer Focus means that institute must know what customer requires exactly, and try to fulfill customer needs and prospect by producing the right product and service. Both external and internal customers must be satisfied with the organization. (Najafabadi et al., 2008)

In addition it is important not only to identify the numerous and different customers of the educational system, but also to identify their requirements in order to satisfy them. The customer requirements refer to the expectations of the customers from the educational system which showed by Sahney et al. (2004).

\subsubsection{Managerial Service.}

infrastructure and other facilities often serve as a major attraction to the end user. Many institutions tune in terms with infrastructural facilities while positioning themselves. A well-equipped classroom promotes better teaching learning process whereas a modern laboratory facility paves the way for better skill acquisition, Institutions cater to the varying needs of the students, teachers and administrators by providing better accommodation, offices, cafeteria, clinics, gymnasiums and good ambience in general Ali et al., (2010).

Almost all of institutions maintaining that the physical site is a stable challenge. However, this requirement should stay at the top of the priority list. In addition institutions should balance the need to deal with the maintenance needs. Although the first is essential, the second will often have more influence on satisfaction levels and perceptions of quality a clean site where public areas are kept attractive and freshly decorated will do much to improve the image of campus as thought by Luxton, (2005). In addition Samuel et al ., (1995) shows the higher education essential equipment such as computing facilities, laboratory equipment and demonstration units require regular maintenance in order to provide services as and when needed. The condition of this equipment has a direct impact on the quality and productivity of teaching and instruction sessions. Petruzzellis, (2006) describe Student satisfaction university education, as an experienced good quality, has to be evaluated. Its intangible component proves to have more importance than the usual intangibility of services, since in the long run it affects the future life of students and the evolution of society as a whole. Many researchers had Classified the managerial service facilities quality infrastructure quality infrastructure, Catering services, free accommodation, sport facilities , medical facilities Availability of infrastructure to host social and cultural events (theatrical plays. cinema) \& Location accessibility of campus Frequency of transport service, cost of transportation, so the criteria relate to students preference for a more flexible service concerning to (Tsinidou, 2010).

\subsubsection{Educational Service}

The main service education is teaching forms the backbone of any educational system. The objective of teaching is the transmission of knowledge from the teacher to the educated ones. Apart form classroom lectures, more innovative teaching can be imparted through other modes plus discussions, case study analysis, presentations, field projects, role play, simulation methods amongst others. Ali et al.,(2010). Also educational services include laboratories, scholarships and internet facilities and library where place library's service availability of textbooks and journals easy borrowing process friendliness, working hours, E-library \& academic staff academic qualifications, professional experience, communication skills, friendliness approachability, links with enterprises, research activity and acquires knowledge to student. As publicized by sakthivel et al.,(2005), (Tsinidou, 2010), and (Petruzzellis, 2006).

Additionally There are many factors related to factor criteria with educational service like Curriculum structure: Interesting module books Educational material of high quality Efficient structure of modules Availability of information on the curriculum structure Variety in elective modules/modules on specialization areas Laboratories (connection with market demands Lectures timetable and Career prospects: Perspectives for 
professional career chances for attending postgraduate programs Opportunities to continue studies abroad Availability of exchange programs with other Institution's relatives with business described by (Tsinidou, 2010).

\subsection{Continuous improvement with TQM.}

(Saheny, 2010) focused on enduring improvement that means improvements for greater customer satisfaction, through improvements in technology and human resources. It involves all the units and requires the optimization of the entire system through interdependency among all the components. The process of continuous improvement, includes people, equipment, supplies, materials, and producers that defined by Temponi, (2005).

More over the Implementing and maintaining a continuous improvement of quality of education in organizations of higher learning is highly attractive and at the same time is challenging as said by Raouf, (2008). The focus should be on improvement of students' learning experience; and learning improvements should be informed by educational theory (Srikanthan, 2007).

Therefore ,the university continuous quality improvement approach called excellence ,a system wide effort by the university to explore the principle of continuous improvement, and total quality management ,project where developed the area of: factually and stuff development and work life enrichment ,assessment of student learning outcomes, under graduation education ,graduate education, student related (student service ), administrative process, technology Evans et al.,(2006)

\subsubsection{P-D-C-A Cycle}

by this method will help this institution to have a continuous improvement (Najafabadi et al., 2008). The enlargement of continuous improvement is normally based upon Plan, Do, Check and Act cycle (PDCA). One of the major principles of continuous improvement is establishment of the self assessment methodology. Its purpose is to regularly evaluate systems inputs, processes and outcomes by adhering to a pre-set framework and methodology thus assisting creation of the basis for strategic and continual improvement of performance, as believed by Raouf,(2008),

Furthermore per Doherty,(2008) and Remond et al.,(2008), Temponi,(2005)and (Raouf, 2008) illustrated the Continues Improvement through cycle is known as the P-D-C-A cycle by a set of steps to be repeated in the pursuit of continuous improvement. The four original major steps of the cycle are: P (plan): gathering of data to identify and define the issues problems that need improvements and identify ways to achieve them. D (do) implementing the plan by using a trial run, a test group, etc. $\mathrm{C}$ (check) analyzing the results to see if there is good agreement between the original goals and what was actually achieved; make adjustments if necessary. A (act): depending on the results from the check step, P (plan): acting on the plan on a full scale or conducting further work. In fact, cycle emphasizes the meaning of continuous improvement in every action and clearly reveals that which step or steps might went wrong in every action (Najafabadi et al., 2008).

\subsubsection{Self Assessment}

The self assessment will include educational as well as others sector of academic institutes affecting elements offered. Criteria pertaining to each of the input to the model have been developed. The self assessment must to be carried out by the department itself. The lead forms the assessment team consisting departmental faculty members and needed faculty from related areas and external peers could also be appointed as members of the assessment team. Raouf,(2008) the assessment result in feedback report, which was handed over and presented during anew visit at university. The report consisted of both strength and improvement possibilities, but did not in most cases, contain detailed suggestion in particular issue. This pointed up by Wiklund et al., (2003).

Temponi,(2005) incorporated a scenario of an institution of higher education conducting the self-assessment process, and considered issues of the faculty component, also assumed that all of the institution's stakeholders had provided input to the faculty component and following issues were identified during the analysis firstly faculty is very dedicated to teaching students secondly faculty is not sufficiently current with technology thirdly students' evaluations on faculty are being partially utilized; fourthly curriculum on some business subjects is lagging behind what is needed by potential employers fifthly faculty are not provided resources to attend conferences and workshops; and finally faculty interaction with businesses in the area where the institution is located is rarely taking place.

(Raouf, 2007) indicated to the Self assessment is a based on several criteria. To meet each criterion a number of standards have to be satisfied as well. The self assessment requires that each program must have program mission, objectives and outcomes. It must have a strategic plan in place to achieve the program objectives. The extent which these objectives have been achieved through continuous assessment and improvement are required 
to be identified and documented. The curriculum is required to be planned to achieve the program objectives and outcomes. Also course objectives are to be in line with program outcomes. The curriculum is required to be in accordance with regulatory body's stipulations. The required laboratories and computing facilities must be adequate available to students and faculty. Students must have enough support to complete the program in a timely manner.

Finally, Self-assessment encourage business excellence by involving a regular and systematic review of processes and results. It highlights strengths and improvement opportunities, and drives continuous improvement (Oakland, 2002).

\section{Conclusion}

Finally after the all discussion above based on literature review and opinion of researcher, the higher education is the most important institution in any country Because the impact in economic and development reflect how the country care of educational and knowledge for the generation as a weapon to fasces others counties. So when there's think about TQM in educational sector that's is mean the graduates give bad or good reputation in educational processes in university.

The subsequent points were completed TQM associated topic in higher education focus on principles and core concept :

- The excellence in education need to focus on student, factually staff, employee as a one hand to gets high quality of output in graduated student.

- The analytical process in this research based on survey in lecture review by identify the important principles to success TQM in higher education and how they implement by discussion

- TQM is strategy which could be practical to several institution based leadership on in education environmental.

- Quality awards and system principles are some of the methodologies that were usually approved but with some kind of little support and many reservations on operational procedures. As an advantage of using the standards available the process of listing was offered, the fact that allowed to provide some incentives for staff taking into consideration the marketing limits. In such a sophisticated system like learning, the inflexibility of the standards of this system was the main factor for the opposing ideas to be put on the table.

Although there were again calls for re-engineering the award system, awards was viewed as the most important incentive for respondents. Most of the responses come to ensure that awards is a distinctive stimulus for encouraging quality improvement within the institutions, or for a great part of them it is a self-assessment criterion; however, if the re-engineering process really occurs the criteria and expressions of assessment would be changed.

\section{Reference.}

1. Ali, M .and Shastri, R.(2010) "Implementation of Total Quality Management in Higher Education". The TQM Journal Vol. 22 No. 2, pp. 175-187 q Emerald Group Publishing Limited.

2. Chapman, D. Adams, D. (2002) "The quality of education: dimension and strategy" Arab development bank publication stock Vol. 5. No 1000701

3. Chen, S. and Yang, C and Shiau, J. and Wang, H. (2006) "The development of an employee satisfaction model for higher education”. The TQM Magazine Vol. 18 No. 5, pp. 484-500 q Emerald Group Publishing Limited.

4. Doherty, G. (2008) “On quality in education Quality Assurance in Education” Vol. 16 No. 3, pp. 255-265 $q$ Emerald Group Publishing Limited.

5. Edmonds, C. (2007) “Continuous quality improvement: integrating best practice into teacher education." International Journal of Educational Management Vol. 21 No. 3, pp. 232-237 q Emerald Group Publishing Limited

6. Evans, J.R. \& Lindsay W.M. (2006) “the Management and Control of Quality", 7th edition Thomson South- Western, Singapore, $70 \mathrm{p}$.

7. Farooq, M., and Akhtar, M. (2007) “application of total quality management Journal” of Quality and Technology Management Volume III, Issue I1, pg 87-97.

8. Guzman A. and Torres j. (2004) “Implications to Total Quality Education" by Education Research Institute, Vol. 5, No. 1, 88-99. 
9. Hussein, B., Najafabadi, N. and Sadeghi, S. Habibzadeh, P.( 2008) "Total Quality Management in Higher Education Case Study" thesis comprises 15 ECTS credits and is a compulsory part in the Master of Science with a Major in Industrial Engineering - Quality and Environmental Management, 60 ECTS credits No. 4/2008.

10. Mehralizadeh, Y. and Haddam, M. (2010) “The applicability of quality management systems and models to higher education A new perspective's" TQM Journal Vol. 22 No. 2, pp. 175-187 q Emerald Group Publishing Limited.

11. Oakland, j. (2002) “Total Quality Management”, 3rd edition, Butterworth-Heinemann, Oxford,

12. Owlia, M. and Aspinwall ,E. (1996) “A framework for the dimensions of quality in higher education” Quality Assurance in Education Volume 4 · Number 2 · pp. 12-20.

13. Osseo-Asare, E., and Longbottom, D., and Chourides, P. (2007) "Managerial leadership for total quality improvement in UK higher education". The TQM Magazine Vol. 19 No. 6, pp. 541-560 q Emerald Group Publishing Limited.

14. Osseo-Asare, E., and Longbottom, D., and Murphy, D. (2005) "Leadership best practices for sustaining quality in UK higher education from the perspective of the EFQM Excellence Model Augustus an”, Quality Assurance in Education Vol. 13 No. 2, pp. 148-170 q Emerald Group Publishing Limited.

15. Petruzzellis, L., (2006) "Student satisfaction and quality of service in Italian universities", Managing Service Quality. 16 No. 4, pp. 349-364 q Emerald Group Publishing Limited.

16. Raouf, A (2008) “Continuous improvement of higher educational”, 2nd International Conference on Assessing Quality in Higher Education, 1st - 3rd December, Lahore - Pakistan.

17. Raouf, A.(2004) "Quality in Higher Education", Proceedings of the Pakistan Academy of Sciences, Vol. 41, issue 2, pp. 165-174.

18. Rausch E. (2007) "Leadership in management education and development: criteria for quality decisions", European Business Review Vol. 19 No. 3, pp. 257-268 q Emerald Group Publishing Limited.

19. Redmond, R. and Curtis, E. and Noone, T. and Keenan, P.(2008) "Quality in higher education the contribution of Edward Deming's Principles". International Journal of Educational Management Vol. 22 No. 5, pp. 432-441 $q$ Emerald Group Publishing Limited.

20. Sahney S., and Banwet K., and S Karunes.(2010) "Quality framework in education through application of interpretive structural modeling an administrative staff perspective". The TQM Journal Vol. 22 No. 1, pp. 56-71q Emerald Group Publishing Limited.

21. Sahney S., and Banwet K., and S Karunes.,(2004) "A SERVQUAL and QFD approach to total quality Education a student perspective" International Journal of Productivity and Performance Management Vol. 53 No. 2, pp. 143-166 q Emerald Group Publishing Limited

22. Sakthivel p. and P.B. And Rajendran G., and Raju R.(2005) 'TQM implementation and students' satisfaction of academic performance".The TQM Magazine Vol. 17 No. 6, pp. 573-589.

23. Sirvanci, M.( 2004 ) “Critical issues for TQM implementation in higher education". The TQM Magazine Volume 16 · Number 6 ·pp. 382-386 q Emerald Group Publishing Limited.

24. Srikanthan. $G$ and Dalrymple, $\mathrm{j}(2007)$ "conceptual overview of a holistic model for quality in higher education”. International Journal of Educational Management Vol. 21 No. 3, pp. 173-193 q Emerald Group Publishing Limited.

25. Temponi, C. (2005) “Continuous improvement framework: implications for academic" Quality Assurance in Education Vol. 13 No. 1, pp. 17-36 q Emerald Group Publishing Limited.

26. Tsinidou, M., Gerogiannis, V, and Fitsilis, P.(2010) "Evaluation of the factors that determine quality in higher education" an empirical study Quality Assurance in Education Vol. 18 No. 3, pp. $227-244 q$ Emerald Group Publishing Limited.

27. Yang, C. (2006) "The impact of human resource management practices on the implementation of total quality management" An empirical study on high-tech firms The TQM Magazine Vol. 18 No. 2, pp. 162-173 $q$ Emerald Group Publishing Limited.

28. Kanji, G.K. and Malek, A(1999) "TQM in UK higher education Institution" Total Quality Management, Vol. 10, NO. 1, 129- 153

\section{$\underline{\text { Report }}$}

29. Apostolu, (2000) A. employee development. Report produced for the ED undid project: INNOREGIO dissemination of innovation and knowledge management technique January.

30. Survey among students in higher education institutions, in the EU Member States, Croatia, Iceland, Norway and Turkey Special Target Survey Analytical Report Fieldwork: February 2009. 